\title{
市販されているコーテッドコンダクター (希土類系超電導テープ線材)の微細組織と臨界電流
}

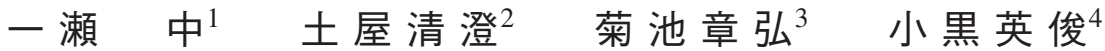

\author{
1一般財団法人電力中央研究所 電力技術研究所 \\ ${ }^{2}$ 大学共同利用機関法人高エネルギー加速器研究機構 \\ ${ }^{3}$ 国立研究開発法人物質 - 材料研究機構 機能性材料研究拠点 \\ ${ }^{4}$ 東海大学 工学部 材料科学科 \\ J. Japan Inst. Met. Mater. Vol. 83, No. 9 (2019), pp. 327-334 \\ Special Issue on The Front Line of Superconducting Materials - Advances in Organizational Control Techniques toward Practical Use \\ (C) 2019 The Japan Institute of Metals and Materials
}

\section{Microstructure and Critical Current of Commercially Available Coated Conductors (Rare-Earth-Based Superconducting Tapes)}

\author{
Ataru Ichinose ${ }^{1}$, Kiyosumi Tsuchiya ${ }^{2}$, Akihiro Kikuchi ${ }^{3}$ and Hidetoshi Oguro ${ }^{4}$ \\ ${ }^{1}$ Electric Power Engineering Research Laboratory, Central Research Institute of Electric Power Industry, Yokosuka $240-0196$ \\ ${ }^{2}$ Inter-University Research Institute Corporation High Energy Accelerator Research Organization, Tsukuba 305-0801 \\ ${ }^{3}$ Research Center for Functional Materials, National Institute for Material Science, Tsukuba 305-0003 \\ ${ }^{4}$ Department of Materials Science, School of Engineering, Tokai University, Hiratsuka 259-1292
}

\begin{abstract}
To adopt coated conductors to various superconducting devices, characteristics such as microstructure and critical current of commercially available coated conductors were investigated. The microstructure was analyzed using a transmission microscope with an energy dispersion spectroscopy. The critical current $\left(I_{\mathrm{C}}\right)$ were measured at $4.2 \mathrm{~K}$ and magnetic fields $(B / / \mathrm{c})$, and at $77 \mathrm{~K}$ and self-magnetic field. As a result of microstructure analyses, the magnetic field dependencies on $I_{\mathrm{C}}$ at $4.2 \mathrm{~K}$ are found to depend on the microstructure of the superconducting layer. Moreover, almost coated conductors were found to have a potential to improve their $I_{\mathrm{C}}$ at $77 \mathrm{~K}$ and self-magnetic field.

[doi:10.2320/jinstmet.JA201904]
\end{abstract}

(Received March 1, 2019; Accepted April 4, 2019; Published May 31, 2019)

Keywords: coated conductor, critical current, microstructure, transmission electron microscope (TEM)

\section{1.は じめに}

1986 年に高温超電導体が発見 ${ }^{1)}$ されて約 30 年が経ち, 臨 界温度が約 $90 \mathrm{~K}$ の第 2 世代と言われている希土類系超電導 体 $\left(\mathrm{REBa}_{2} \mathrm{Cu}_{3} \mathrm{O}_{\mathrm{y}}, \mathrm{RE}: \mathrm{Y}, \mathrm{Gd}, \mathrm{Eu}\right.$ 等の希土類元素)に薄膜技 術を適用し，金属テープ上に $\mathrm{CeO}_{2}$ 等の中間層を介して 2 軸 配向した超電導層を作製した超電導テープ線材 (Coated Conductors)が市販されるようになった，長尺化が先行して いる第 1 世代の Bi2223 線材と同様に様々な超電導機器への 適用が検討されつつある ${ }^{2-6)}$ 。超電導機器を設計, 作製する には, 線材の電気特性, 機械特性, 熱特性等の諸特性が必要 となる中で, 電気特性はどれくらいの電流が流せるかという 臨界電流值が基本的な特性となる. 超電導材料の電気特性の 指標として単位断面積当たりに流れる電流を表す臨界電流密 度 $J_{\mathrm{C}}$ が使用されるが, 超電導線材あるいは導体に加工する と, 超電導材料以外の材料との複合材料となるため, 他の材 料を含めた線材の総断面積あたりの臨界電流密度を示す $J_{\mathrm{e}}$ が新たな電気特性を示す指標となる。しかし, これも断面積
の值がわからなければ，どれくらいの電流が流れるかを知る ことができない. また, 超電導テープ線材のように扁平で, 超電導層以外の部材が大半の厚さを有しているテープ線材で は単位幅あたりの臨界電流值 $I_{\mathrm{C}}$ が機器設計にとって重要と なる。

超電導テープ線材の作製方法は金属テープの取扱により大 きく分けて 2 通りの作製方法に分類される. 1 つは, Rolling-Assisted Biaxial-Textured Substrate 法 $^{7)}$ (RABiTS 法)と 呼ばれる方法で, 金属を圧延と熱処理によって治金学的に 2 軸配向させた金属テープを作製する方法である.この金属 テープ上に拡散防止中間層と超電導層をエピタキシャル成長 させ， 2 軸配向した超電導層を作製する方法である．当初は 金属材料として純ニッケル $(\mathrm{Ni})$ が使用されることが多かった が，市販の線材では Ni の磁性を無くすためにタングステン （W）を添加した金属基材が使用されるようになった。さら に，2 軸配向した銅を主体として，機械的強度を持たせるた めに SUS と貼り合わせ，銅の高い反応性を抑制するために 表面処理した金属テープを用いる場合もある。もう1つは, Ion-Beam Assisted Deposition 法8) (IBAD 法) と呼ばれる方法 
で, 結晶配向のランダムな金属テープ上に斜めからアルゴン イオン $\left(\mathrm{Ar}^{+}\right)$ビームを照射しながら酸化物層を形成すること により，室温で 2 軸配向した酸化物中間層を作製し，その上 にエピタキシーに 2 軸配向した超電導層を作製する方法であ る. 当初は酸化物中間層としてイットリア安定化ジルコニア (YSZ) あるいは $\mathrm{Gd}_{2} \mathrm{Zr}_{2} \mathrm{O}_{7}$ を使用していたが, $\mathrm{MgO}$ が約 10 $\mathrm{nm}$ の厚さで良好な 2 軸配向性を示すことがわかったため ${ }^{9)}$, 製造速度の高速化の観点から市販線材には IBAD-MgO が使 用されている．IBAD 法の場合には，金属テープの材料は制 限されないために, 金属テープは機械特性, 熱特性, 価格等 を加味して自由に選択することができる，しかし，ほとんど の市販線材では $\mathrm{Ni}-\mathrm{Cr}$ 系合金のハステロイが使用されてい る.この論文で評価した線材には含まれていないが，ハステ ロイ以外にステンレスを使用した線材もある。このように, 超電導テープ線材は金属テープの取扱方法が異なり，それに より金属テープの材料が異なる．また，金属テープが 2 軸配 向しているかどうかで，酸化物中間層の材料および中間層の 層数も含めて中間層の作製方法が異なる.ささらに, 酸化物中 間層上に作製する超電導層においても, 希土類元素の種類, 超電導層の作製方法を選択することができる．超電導層の作 製方法においては, パルスレーザー蒸着法(PLD 法)や, 有 機酸塩を原料にした Metal Organic-Chemical Vapor Deposition (MO-CVD) 法や, トリフルオロ酢酸塩の溶液を塗布して熱 分解により超電導層を作製する方法 (TFA-MOD 法 : Metal Organic Deposition using Trifluoro-Acetates)などの様々な超電 導層の作製方法がある. 製造メーカはこれらの金属テープ, 中間層, 超電導層の材料および作製方法の中から独自の組合 せを用いて超電導テープ線材を製造する. したがって, 線材 メーカから製造・販売されている超電導テープ線材は, その 諸特性は様々であることが予想される，また，線材を購入す る際には, 線材の電気特性を含んだ諸元が提供されるが, そ れに関しても測定条件の違い等により横並びに比較すること は難しいことがある. そこで, 入手可能な超電導テープ線材 の臨界電流 $I_{\mathrm{C}}$ を同じ条件, 同じ方法で測定することは, 超 電導テープ線材を超電導機器に適用する際にとても重要な情 報となる. Table 1 に線材メーカ提示の超電導テープ線材の 諸元を示す。なお,「2.2 臨界電流測定」で詳細に記載するが, 今まで10,11) および今回測定した超電導テープ線材の臨界電流 $I_{\mathrm{C}}, n$ 值, 微細組織より見積った超電導層の厚さ, および,
見積った超電導層の厚さから求めた臨界電流密度 $J_{\mathrm{C}}$ とメー 力提示の諸元から求めた工学的臨界電流密度 $J_{\mathrm{e}}$ を Table 1 に 示す．本論文では，これらの超電導テープ線材の縦断面およ び超電導層の横断面を透過型電子顕微鏡 $(\mathrm{TEM})$ で観察し, 臨界電流との関係を示した。これにより，各線材メーカの超 電導テープ線材の特性向上のポテンシャルの提示あるいは最 適適用箇所の提案を可能とするデータベース作成の一助にな ることを目的とする.

\section{2. 実 験 方 法}

\section{1 微細組織評価}

線材を数 $\mathrm{cm}$ の長さに切り, 約 $4 \mathrm{~mm}$ 幅の線材を立てた状 態でクリップに挟み, クリップと一緒に導電性樹脂に埋め込 んだ。導電性樹脂を用いた理由は，切断，研磨後にそのまま 集束イオンビーム装置(FIB 装置)にセットして加工ができる ようにするためである。導電性樹脂に埋め込んだ線材は，4 $\mathrm{mm}$ 幅のほぼ中央が表面に出るように切断し, 機械研磨で表 面処理を行った。FIB 装置に挿入した樹脂埋めした線材は, マイクロサンプリング法により, 必要な部分を切出し, TEM 観察用のグリッド上にセットして薄片化した。線材を 切り出す際に, 2 つの方向で切出すことにより, 超電導テー プ線材の断面組織観察用試料と超電導層の横断面(平面)組織 観察用試料を作製した。 断面組織観察用試料は, 金属テープ と垂直方向に切出し薄片化した。超電導層の横断面組織観察 用試料は，金属テープと並行に切出し，超電導層部分が残る ように薄片化した。微細組織観察は Energy Dispersive X-ray Spectroscopy (EDX)を搭載したJEOL JEM 2100Fを用いて走 査透過電子顕微鏡 $(\mathrm{STEM})$ 像を取得し, 必要があれば EDX を用いて STEM 像に対応した元素マッピング像を取得した. さらに，結晶配向を調べるために，TEM 像および制限視野 回折パターンを取得した.

\section{2 臨界電流測定}

4.2 K で, 磁場をテープ線材の法線方向に印加した際の磁 場中の臨界電流の測定方法の概略を記載する. 詳細は参考文 献 10)，11）を参照していただきたい. $4.2 \mathrm{~K}$, 磁場中の $I_{\mathrm{C}}$ 測 定用の U 字型治具を作製し, そのU 字型治具に長さ $200 \mathrm{~mm}$ の線材を沿わせて 4 端子法で測定した．U 字型治具の縦方向

Table 1 Characteristics of commercial coated-conductors.

\begin{tabular}{|c|c|c|c|c|c|c|c|c|c|c|}
\hline Conductor & $\begin{array}{l}\text { Fabrication } \\
\text { Technology }\end{array}$ & $\begin{array}{c}\text { Substrate * } \\
\text { thickness }(\mu \mathrm{m})\end{array}$ & $\begin{array}{l}\text { Cu stabilizer * } \\
\text { thickness }(\mu \mathrm{m})\end{array}$ & 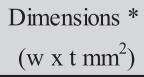 & $\begin{array}{c}I_{\mathrm{C}}(\mathrm{A}) 4 \mathrm{mmW} \\
(77 \mathrm{~K}, \text { s.f. })\end{array}$ & n-value & $\begin{array}{c}\text { Thickness } \\
(\mathrm{nm})\end{array}$ & $\begin{array}{c}J_{\mathrm{C}} \\
\left(\mathrm{MA} / \mathrm{cm}^{2}\right)\end{array}$ & $\begin{array}{c}J_{\mathrm{e}} \\
\left(\mathrm{MA} / \mathrm{cm}^{2}\right)\end{array}$ & $\begin{array}{c}\text { Acquisition } \\
\text { Year/Month }\end{array}$ \\
\hline (a) AMSC (US) & RABiTS/MOD & $75(\mathrm{NiW})$ & 60 & $4.8^{\mathrm{a}} \times 0.20$ & 144.5 & 37 & 1360 & 2.66 & 0.015 & $2016 / 4$ \\
\hline (b) Fujikura(JP) $)^{12)}$ & IBAD/PLD & 75 (Hastelloy) & 20 & $4.1 \times 0.12$ & 225.5 & 34 & 1617 & 3.49 & 0.030 & $2015 / 9$ \\
\hline (c) Shanghai SC $(\mathrm{CN})^{13)}$ & IBAD/PLD & 50 (Hastelloy) & 10 & $4.8 \times 0.07$ & 145 & 27 & 968 & 3.74 & 0.071 & $2016 / 9$ \\
\hline (d) Sumitomo (JP) & RABiTS/PLD & $100(\mathrm{Cu} / \mathrm{SUS})$ & $14-20$ & $4.1 \times 0.21$ & 200 & 32 & 5242 & 0.95 & 0.025 & $2017 / 9$ \\
\hline (e) SuNAM $(K R)^{14)}$ & IBAD/RCE-DR & 60 (Hastelloy) & 20 & $4.1 \times 0.10$ & 217 & 43 & 1325 & 4.09 & 0.033 & $2015 / 11$ \\
\hline (f) SuperOx $(R U)^{15)}$ & IBAD/PLD & 60 (Hastelloy) & 40 & $4.0 \times 0.15$ & 132 & 36 & 1890 & 1.75 & 0.019 & $2015 / 12$ \\
\hline (g) SuperPower1 (US) ${ }^{16)}$ & IBAD/MOCVD & 50 (Hastelloy) & 20 & $4.0 \times 0.10$ & 156 & 30 & 1196 & 3.26 & 0.022 & $2015 / 8$ \\
\hline (h) SuperPower2 (US) ${ }^{16)}$ & IBAD/MOCVD & 30 (Hastelloy) & 5 & $4.0 \times .0 .045$ & 150 & 29 & 1191 & 3.15 & 0.083 & $2016 / 9$ \\
\hline
\end{tabular}

*: Manufacture information, ${ }^{\text {a }}$ : Superconductor width is $4.0 \mathrm{~mm}$. 
の直線部分は $75 \mathrm{~mm}$ でその両端で電流端子と接続した。横 方向の直線部分は $45 \mathrm{~mm}$ で, 電圧端子間距離を $30 \mathrm{~mm}$ とし た. 磁場は横方向に沿わせた線材の法線方向に印加した. し たがって，U 字型字具の縦方向に沿わせた線材には平行磁場 が印加されることになる. $45 \mathrm{~mm}$ の横方向の $30 \mathrm{~mm}$ 間の電 圧端子以外に縦方向から横方向への曲がり部(左右両方で 2 箇所)，および，電流端子間の近傍の線材長さが約 $1300 \mathrm{~mm}$ の部分に電圧端子(左右両方で 2 箇所)を準備し，曲がり部で の $I_{\mathrm{C}}$ の低下がないか, 縦方向に沿わせた線材で $I_{\mathrm{C}}$ が制限さ れずに横方向に沿わせた部分の $I_{\mathrm{C}}$ を測定しているかを確認 した，線材は，超電導層に圧縮応力がかかるように，金属 テープを外側に，超電導層を内側になるようにU 字型治具 に沿わせたままた，77 K, 自己磁場の臨界電流は，U 字型ホ ルダーを使用して $4.2 \mathrm{~K}$ の臨界電流特性を測定する前に，液 体窒素に浸漬して測定した。全ての測定で臨界電流を決める 電界基準は $1 \mu \mathrm{V} / \mathrm{cm}$ とした。 $77 \mathrm{~K}$, 自己磁場の臨界電流の 結果 $(4 \mathrm{~mm}$ 幅)を Table 1 に示す。断面組織観察より見積った
超電導層の厚さを用いて求めた超電導層の臨界電流密度 $J_{\mathrm{C}}$, 金属基材，安定化銅を含めたメーカからの超電導テープ線材 の寸法を用いて求めた工学的臨界電流密度 $J_{\mathrm{e}}$ も Table 1 に示 す.

\section{3. 微細組織解析結果}

Table 1 に示した 8 本の超電導テープ線材の断面組織の STEM 像を Fig. 1 に示す. 超電導テープ線材により超電導層 の厚さが異なるため各 STEM 像の長さスケールは異なる.

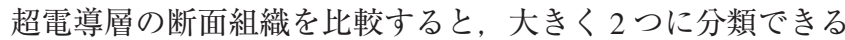
ことがわかる.1つは線状のコントラストが見られる組織 と，もう1つは粒状のコントラストが見られる組織である. 線状のコントラストにおいて，法線方向のコントラストは, らせん転位, 超電導結晶の粒界, 人工ピンのナノロッド，水 平方向のコントラストは積層欠陥, マルチコートによる欠骝 構造等が考えられる。また，粒状のコントラストは，後で示
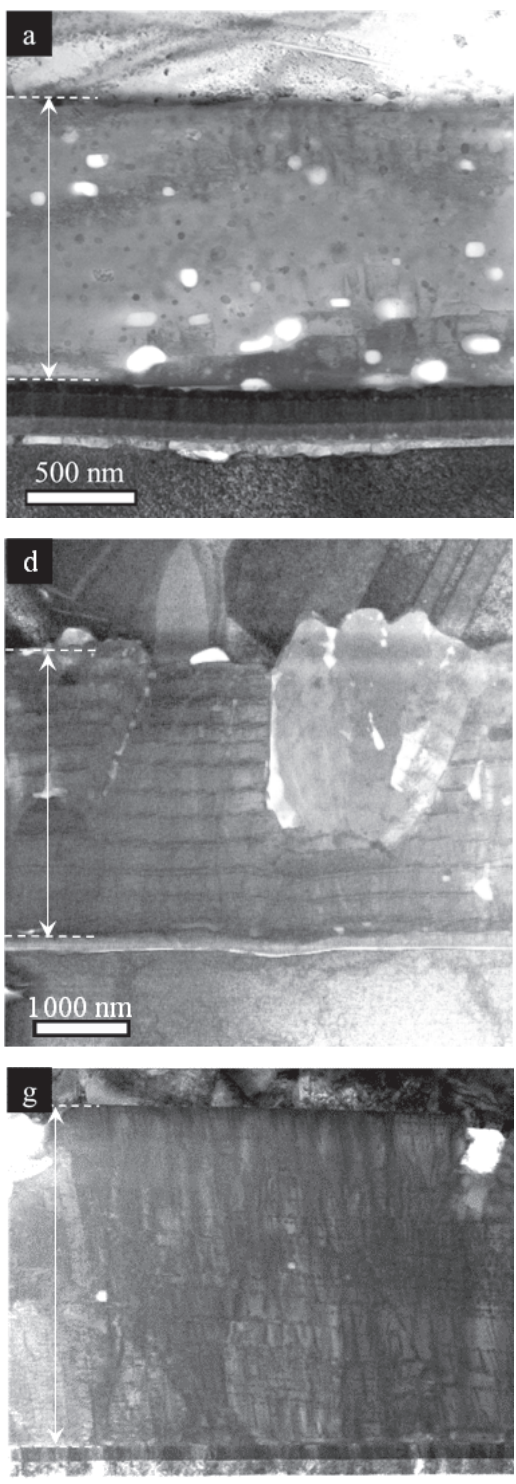

\section{$500 \mathrm{~nm}$}
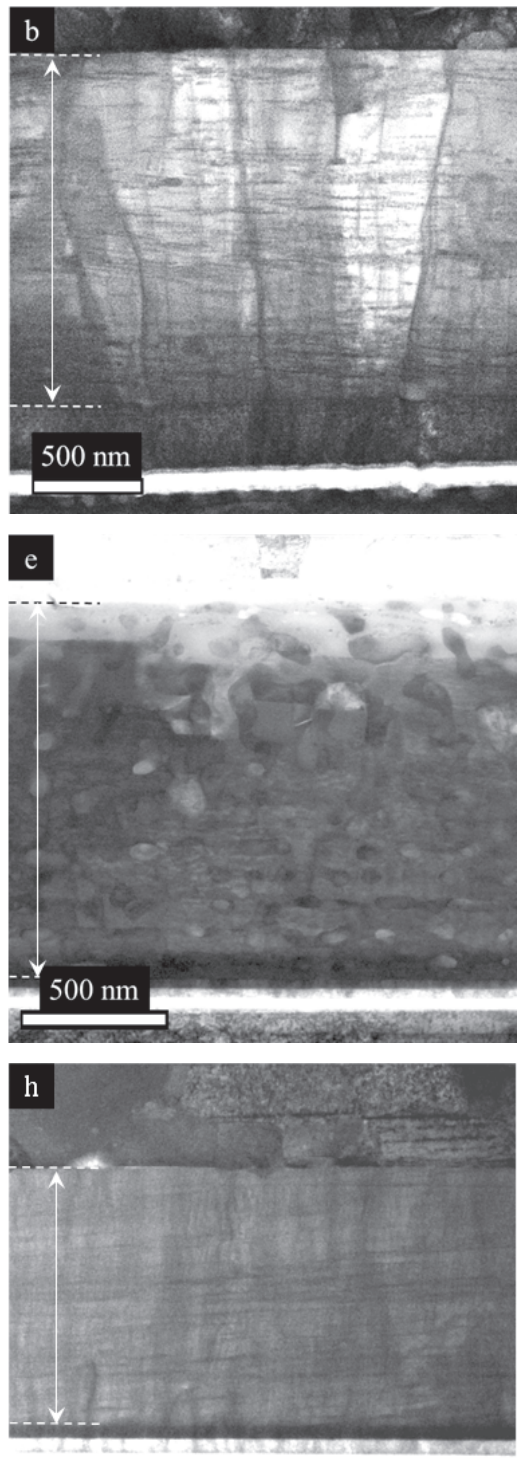

$500 \mathrm{~nm}$
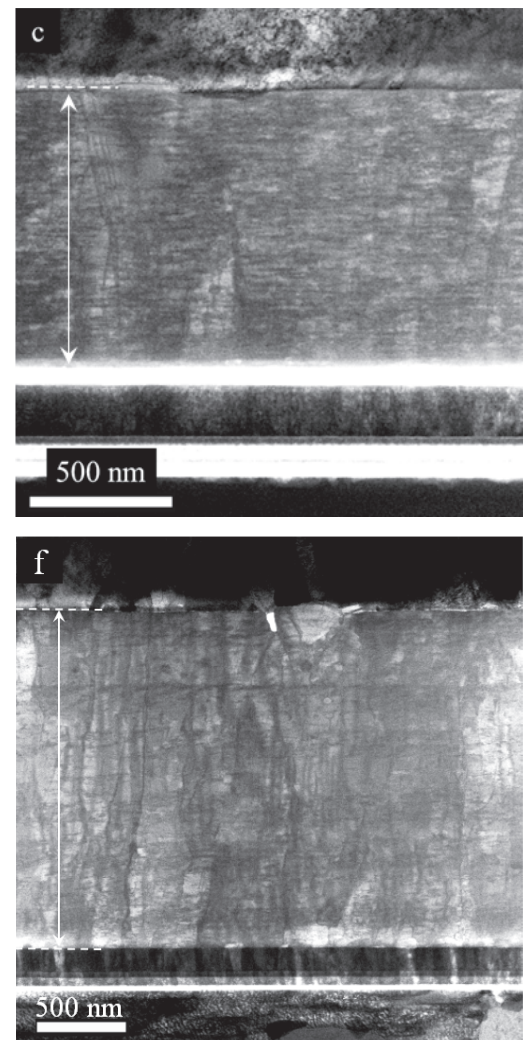

$500 \mathrm{~nm}$

its

Fig. 1 Cross-sectional STEM images of (a) AMSC, (b) Fujikura, (c) Shanghai SC, (d) Sumitomo, (e) SuNAM, (f) SuperOX, (g) SuperPower1 and (h) SuperPower2. 
す SuNAM 線材の断面組織の元素マッピングの結果(Fig. 7) からわかる様に, 超電導層内部の異相の分布に対応している と考えられる．2つの組織の概念図を Fig. 2(a)，（b)にそれ ぞれ示す。これらの組織の違いは, 超電導層の作製方法の違 いによる物と考えられる. Fig. 1 で Fig. 2(a)の組織をもつ線 材は Fig. 1(b-d, f-h)で, Fig. 2(b)の組織をもつ線材は Fig. 1 (a, e)である. Fig. 2(a)の組織をもつ線材の作製方法は Table 1 より MO-CVD 法, PLD 法である. Fig. 2(b)の組織をも つ線材は Table 1 より TFA-MOD 法, Reactive Co-Evaporation by Deposition and Reaction (RCE-DR) 法である. MO-CVD 法, PLD 法は膜の堆積と結晶化が同時に行われるプロセスであ るのに対し, TFA-MOD 法, RCE-DR 法は膜の堆積後に結晶 化を行うプロセスである. この超電導層の作製方法のプロセ スの違いにより超電導層の結晶成長機構が大きく異なり, 組 織が変化したと考えられる.

Fig. 2(a)に分類される線材の中で $\mathrm{BaZrO}_{3}$ ナノロッドの人 工ピンが導入されている線材は, Table 1 の (f)〜 (h)で, 人 工ピンが導入されてない線材は $(\mathrm{b}) \sim(\mathrm{d})$ である. (d)の超電 導テープ線材以外の線材は, 断面組織を見る限りでは, 人工 ピンの有無を明確に判断することは難しい. どの超電導テー プ線材もテープ面の法線方向にコントラストの異なる細い線 状の物が分布している. 断面組織では大きな違いが見られな いため, 人工ピンが導入されていない超電導テープ線材 $(\mathrm{b})$, 人工ピンが導入されている超電導テープ線材 $(\mathrm{g}),(\mathrm{h})$ の $3 つ$ の超電導テープ線材を選んで超電導層の平面組織を観察し た.この 3 つの超電導テープ線材は $4.2 \mathrm{~K}$ の磁場中の臨界電 流が測定磁場範囲の全域で臨界電流值が高い 3 本の線材であ
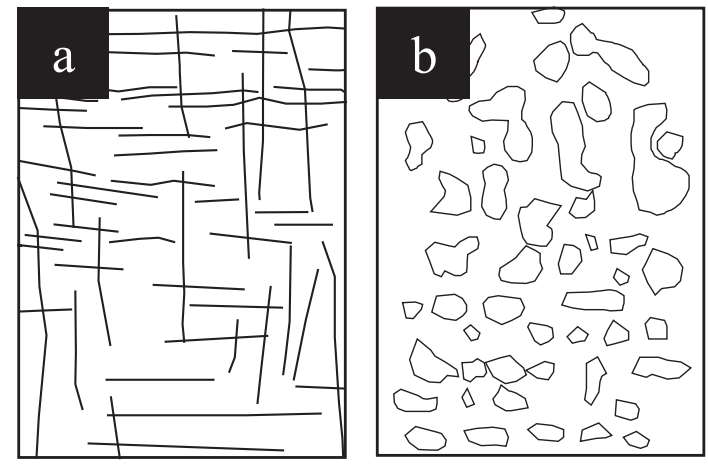

Fig. 2 Schematic diagrams of two types of cross-sectional microstructures.
る. Fig. 3(a-c) に線材 (b)，（g)，（h)の平面 STEM 像を示す. Fig. 3(b)より線材 $(\mathrm{g})$ では線の幅が 8〜10 nm の短い線あるい は点が分散している. また, Fig. 3(c)より線材(h)では約 5〜 $7 \mathrm{~nm}$ の点が分散している. 一方, 線材 (b)では, そのような 点状の物が確認できない. したがって, Fig. 3(b, c) の超電 導層全域に分散している点状の物が人工ピンの $\mathrm{BaZrO}_{3}$ ナノ ロッドをロッドが伸びた方向から見た組織である。全てのナ ノロッドが超電導層の法線方向に平行とは限らず傾斜してい ることがある。これは断面組織の Fig. 1 ( g) で確認できる. ナノロッドが法線方向から少し傾いて分布する場合には, 平 面組織を観察する約 $100 \mathrm{~nm}$ の超電導層の厚さの領域を斜め に横断するため, 上から見た際に, 点ではなく短い線として 観察される.これが, Fig. 3(b)で観察されている.この点状 の物が人工ピンの $\mathrm{BaZrO}_{3}$ であることを確認するため, 線材 (g) と (h) の STEM 像およびマッピングデータを Fig. 4(a, b) にそれぞれ示す. 点状, 短い線状の組織から $\mathrm{Zr}$ が検出され, $\mathrm{BaZrO}_{3}$ であることがわかる。 また，低倍率の EDX マッピン

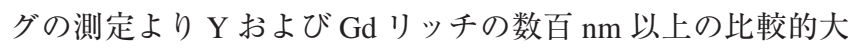
きな塊が測定されており，断面組織で超電導層における水平 方向から数度傾いた厚さ数 $\mathrm{nm}$ のコントラストの異なるもの であると考えられる．以上のことから，線材 $(\mathrm{b}),(\mathrm{g}),(\mathrm{h})$ の断面組織は類似の組織を有しているが, 法線方向に伸びる 暗いコントラストの線状の物は, 線材 (b)では人工ピンでは なく, 転位等の膜が成長する際に生成した欠陥であると考え られ, 線材 $(\mathrm{g}),(\mathrm{h})$ では主に人工ピンの $\mathrm{BaZrO}_{3}$ ナロッドで ある。

\section{4. 臨界電流と微細組織の関係}

超電導層の作製プロセスの違いにより，微細組織が大きく $2 つ に$ 分類されることがわかった．磁場を超電導テープ面の 法線方向に印加した際の $4.2 \mathrm{~K}$ の臨界電流の磁場依存性を Fig. 5 に示す. Fig. 5 によると, $4.2 \mathrm{~K}$ の臨界電流の磁場依存 性がほぼ同じグループ 1 と磁場による臨界電流の低下が少な いグループ 2 に大別される.グループ 1 の線材は, 断面の微 細組織観察により分類された粒状の組織が観察された線材 で, 膜の堆積後に結晶化が行われるプロセスで作製された線 材である. グループ 2 の線材は, 断面の微細組織観察で, 線 状の組織が観察された線材で，膜の体積と結晶成長が同時に 行われるプロセスで作製された線材である．超電導層の作製
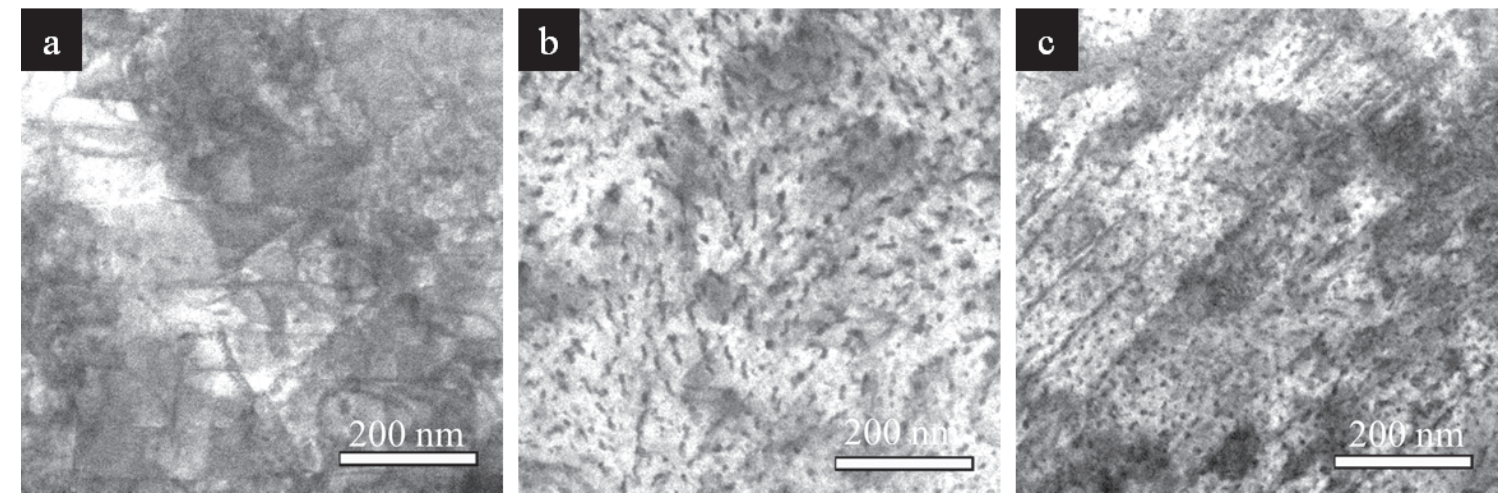

Fig. 3 Plan-View STEM images of (a) Fujikura, (b) SuperPower1 and (c) SuperPower2. 

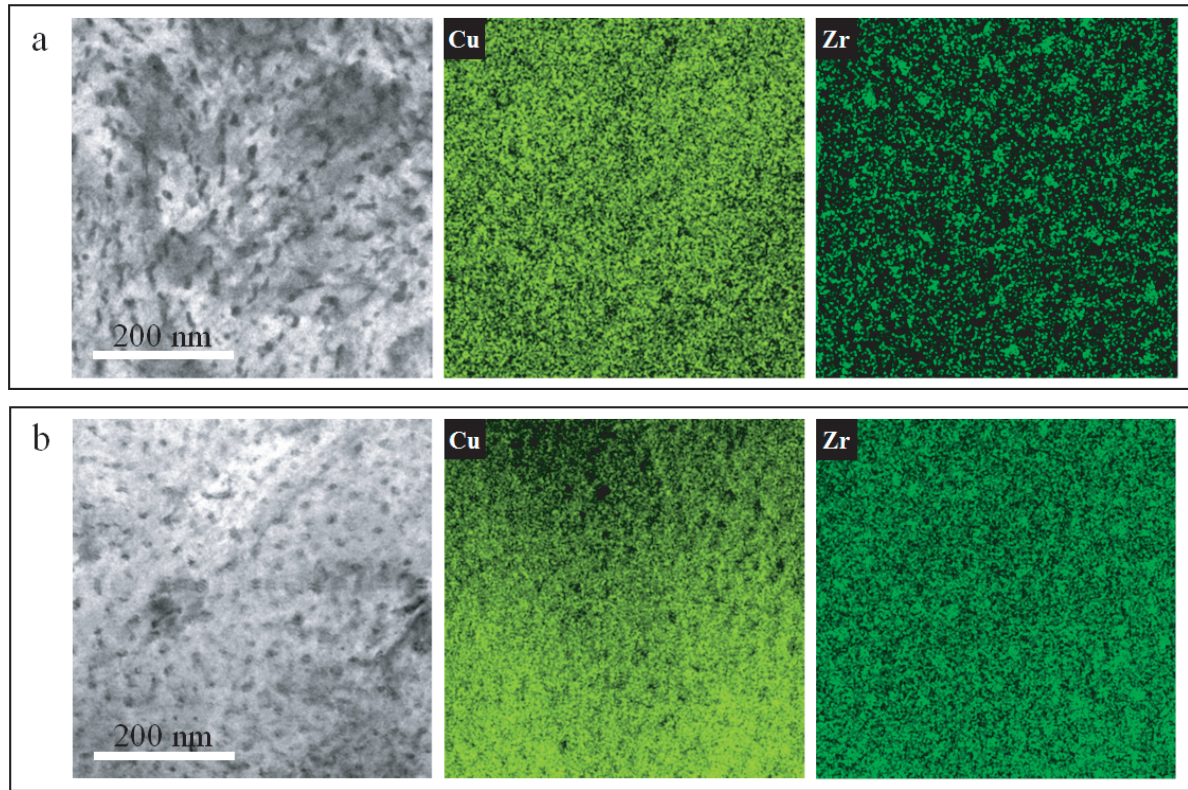

Fig. 4 Plan-View STEM images and EDX mappings of $\mathrm{Cu}$ and $\mathrm{Zr}$ for (a) SuperPower1 and (b) SuperPower2.

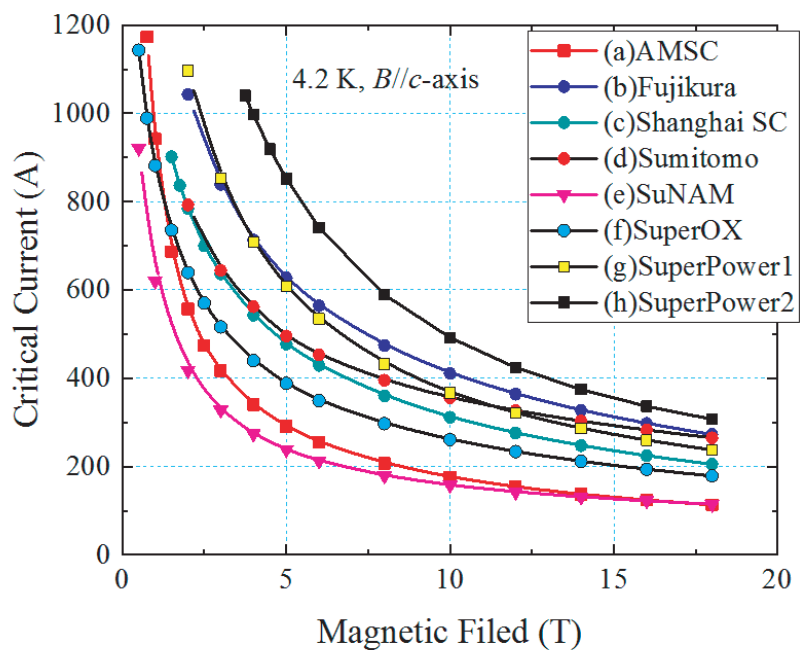

Fig. 5 Magnetic field dependencies of critical current, $I_{\mathrm{C}}$, for 4$\mathrm{mm}^{-}$wide conductors for commercial coated-conductors in perpendicular magnetic fields at $4.2 \mathrm{~K}$.

プロセスの違いにより生じた微細組織の違いが, 磁場を線材 のテープ面に垂直に印加した $4.2 \mathrm{~K}$ の臨界電流の磁場依存性 に影響したと考えられる。つまり，粒状の組織が観察された 線材は, $4.2 \mathrm{~K} て ゙$ 有効に働くピンニングサイトが無く, 磁場 が印加されると臨界電流の低下が大きい。一方, 線状の組織 が観察された線材は，テープ面に法線方向に有効に働くピン ニングサイトが存在し，それにより臨界電流の低下が抑制さ れる. また，ピンニング力の強さにより低下の度合いが異な るため，臨界電流の低下は幅を持つと考えられる.

次に, $\mathrm{BaZrO}_{3}$ ナノロッドの人工ピンの $4.2 \mathrm{~K}$, 磁場中 $(B / /$ c) の臨界電流に対する効果について検討する. 前にも述べた が, グループ 2 の中で人工ピンの $\mathrm{BaZrO}_{3}$ ナノロッドが導入 されていない線材は $(\mathrm{b}) \sim(\mathrm{d}) て ゙$, 導入されている線材は (f)〜 (h) である. $4.2 \mathrm{~K}, 10 \mathrm{~T}$ の臨界電流の值の大きい順に 並べると, 線材 $(\mathrm{h})$ (人工ピンあり), 線材 (b) (人工ピンな し), 線材 $(\mathrm{g})$ (人工ピンあり), 線材 $(\mathrm{d})$ (人工ピンなし), 線
材 (c) (人工ピンなし), 線材 (f) (人工ピンあり)となり, 臨界 電流の大小は人工ピンの有無とは全く相関がないように見え る. $\mathrm{BaZrO}_{3}$ ナノロッドは液体窒素および過冷却窒素温度の 比較的高い温度領域では，コヒーレンス長とナノロッド径が ほぼ同じ長さになり, 非常に強いピンニングセンターとして 働くと考えられている. $4.2 \mathrm{~K}$ の極低温では, コヒーレンス 長が短くなるため, ピンニング力が弱まり, 臨界電流の磁場 印加角度依存性で $B / / c$ の $I_{\mathrm{C}}$ のピークは観察されなくなる が, 超電導体の異方性は緩和されていることから十分にピン ニングセンターとして機能していると考えられている ${ }^{17)}$. したがって, 今回の測定結果においても $\mathrm{BaZrO}_{3}$ ナノロッド の人工ピンは全く効果が無いということではないと考えられ る.そこで, 微細組織においてナノロッドの有無を確認した 線材 $(\mathrm{b})$, 線材 $(\mathrm{g})$, 線材 (h) について議論する. 特に, 線材 (g) と (h) は同じメーカの線材であることから, その組織を比 較することで臨界電流と微細組織 (人工ピン) との関係が理解 できると考える. Fig. 3(b, c) の平面 STEM 像から線材 $(\mathrm{g})$ の ナノロッド径は約 8〜10 nm で, ナノロッドは僅かな角度の 範囲で法線方向 $(B / / C)$ から摇らいで分布している. また, 線 材(h)のナノロッド径は約 5〜 7 nm で, ナノロッドはテープ 面の法線方向 $(B / / C)$ にほぼ向いて配列していることがわか る.この微細組織の結果から, 線材(h)のナノロッドは線材 ( $\mathrm{g})$ のナノロッドより細く，きれいに配列していることから， 有効に機能することが予想される。実際に, 臨界電流は線材 (h)の方が 1.2 倍程, 全ての測定磁場範囲で高い值を有して いる. また, 線材 $(\mathrm{g})$ の臨界電流は, 人工ピンが入っていな い線材 (b) とほぼ同じ值である. 以上のことから， $4.2 \mathrm{~K}$ の極 低温になると, $77 \mathrm{~K}$ 近傍で強力な $\mathrm{c}$ 軸相関ピンとして機能 した $\mathrm{BaZrO}_{3}$ ナノロッドは, 効果的なピンニングセンターで 無くなり, 他の欠陥と同等のピンニング効果となるが, ナノ ロッド径を細く，方向を十分に制御できれば， $4.2 \mathrm{~K}$ の極低 温でも大きなピンニング効果が期待できると考えられる.

$4.2 \mathrm{~K}$ の超電導利用では主に高磁場マグネット応用となる 
が, ケーブル, 限流器, 風力発電機という超電導機器に超電 導テープ線材を適用する際には, $4.2 \mathrm{~K} よ り$ 高い温度で使用 することになる．超電導機器により運転温度は異なるが, こ こでは $77 \mathrm{~K}$ の温度領域での臨界電流 $I_{\mathrm{C}}$ を検討する ${ }^{18)}$. Table 1 より, $77 \mathrm{~K}$, 自己磁場下での臨界電流が $200 \mathrm{~A}$ を越える線 材が 3 つあ. $4 \mathrm{~mm}$ 幅で $200 \mathrm{~A}$ を越えるということは, 超 電導層の厚さが $1 \mu \mathrm{m}$ とすると, 臨界電流密度は $5 \mathrm{MA} / \mathrm{cm}^{2}$ 以上となり, かなり高い值となる。このような, 高臨界電流 密度を有する超電導層を長尺で作製するのは，現状ではかな り難しい, そのため, 高臨界電流化は超電導層の厚さを厚く する方向で開発が進められている. Table 1 に断面組織観察 から見積った超電導層の厚さを示す. $200 \mathrm{~A}$ を越える臨界電 流をもつ超電導テープ線材の膜厚は, 超電導テープ線材 $(\mathrm{b})$ では $1,617 \mathrm{~nm}$, 超電導テープ線材 $(\mathrm{d})$ では $5,242 \mathrm{~nm}$, 超電導 テープ線材 $(\mathrm{e})$ では $1,325 \mathrm{~nm}$ である.ここに示す全ての超電 導テープ線材は, 超電導層の厚さを厚くするためマルチコー ト法が採用されている，超電導テープ線材 (d) と (e) は, 断面 組織観察よりマルチコートに対応した層状構造が確認でき る. 一方, 超電導テープ線材 (b)では, マルチコートに対応 した層状構造が明瞭に観察されない. 超電導テープ線材 (e) では, RCE-DR 法の特徵である膜の堆積後に結晶化を行う プロセスを多数回繰り返すため未反応物が各層毎に観察さ れ, 層状構造が確認できる. 超電導テープ線材 (b) と (d) は, 両方とも PLD 法で作製しているが, 超電導テープ線材 (b)で 層状構造が明瞭に観察されない要因として, 超電導層の作製 方法に成膜温度が極めて安定な Hot-wall Heating 法 ${ }^{19)}$ が採用 されているためだと考えられる。一般に, 超電導層が成長す る場合, 下地材料が異種材料の場合には僅かな格子整合性の 違いにより成長初期には微細な欠陥等が入り結晶が乱れる. また, ホモエピタキシャルの場合にも, 表面状態の違いよ り，異種材料の場合と同様に結晶に乱れが生じることがあ る. マルチコート法では, 各層毎にトータルの超電導層の厚 さが異なり，また，均熱帯と考えられている空間内で物理的 に場所が異なるなど，表面状態が全く同じとは言えない。そ のため, ホモエピタキシャル成長でも各層の成長初期は何ら かの欠陥が導入され結晶が乱れ, その後, 乱れが緩和されて きれいな結晶が成長する。この過程を繰り返すことになる. これを言い換えれば, 各層毎に結晶成長がリセットされる. Hot-wall Heating 法では成膜温度が極めて安定なため, 各層 毎に結晶成長がリセットされずに断面組織のどの部分を見て も，ほぼ同じ組織を有している。しかし，結晶成長がリセッ トされないため超電導層が厚くなるにしたがい, 結晶成長が 進み, 結晶が肥大化すると考えられる，以上のことを念頭に おいて, Fig. 1(b)の断面組織を見直すと, 結晶が僅かに肥大 化しているように見える. 臨界電流に関して各層毎に結晶成 長がリセットされるのが良いのか, リセットされない方が良 いのか, 他の要因との兼ね合いから一概にどちらが良いとは 言えないが, どちらの場合にも良く制御されていることが重 要である. マルチコート法で, 各層毎に結晶成長がリセット される場合には, 超電導層の厚さが厚くなるに従い, 初期の 結晶成長条件と異なる条件になる可能性が高い. 超電導線 テープ線材 $(\mathrm{d})$ と (e) とも超電導層の金属テープ面近傍と超電
導層の表面付近の組織が変化していることがわかる. 超電導 テープ線材 (d) では, マルチコートの 3 層目あたりから $\mathrm{a}$ 軸 配向が成長していることがわかる。この線材の超電導層部分 の平面組織を Fig. 6 に示す. いくつかの領域の制限視野電子 線回折も Fig. 6 に示す. 電子線回折から領域 $\mathrm{c}$ と d は a 軸配 向粒で, 領域 $\mathrm{b}$ は $\mathrm{c}$ 軸配向であることがわかる. 電子線回折 の結果より Fig. 6 の破線で囲んだ領域は a 軸配向粒であると 考えられる.ささらに, 平面組織から $\mathrm{a}$ 軸配向と $\mathrm{c}$ 軸配向の境 界に明るい部分が存在し，隙間があるか非常に結合が弱いこ とがわかり, 超電導電流の流れを阻害する部分が多数存在す ることがわかる. したがって, 超電導テープ線材 (d) は, a 軸配向粒を無くせば, さらに, 臨界電流が向上することが明 らかである。また， $\mathrm{a}$ 軸配向粒は基板温度が低下することに より生成することが知られていることから ${ }^{20,21)}$, 多層化する にしたがい，表面温度が低下したか，表面状態が変化し飛来 した原料のマイグレーション距離が短くなったため, あるい は，その両方が生じていると考えられる。 また，超電導テー プ線材 (e)では, 粒状の組織の粒の大きさが, 表面近傍にな ると肥大化するとともに, 層をまたいで肥大化しているのが わかる. 断面組織だけではわかり難いので, 元素マッピング の結果を Fig. 7 に示す, 元素マッピングの結果より, 粒の大 きさが肥大化し, 明らかに結晶の成長の条件が変化している ことがわかる．また，銅酸化物と思われる銅のシグナルが強 く検出されている粒子が表面に近づくにつれて大きくなり, 増えていることがわかる. $\mathrm{BaZrO}_{3}$ ナノ粒子入りの TFA$\mathrm{MOD}$ の例であるが, マルチコートの 1 層あたりの層の厚さ を薄くすることにより, 結晶粒を小さくし, 臨界電流特性が 向上した報告がある ${ }^{22)}$. このことから, 超電導テープ線材 (e)において，表面近傍での粒の肥大化を抑制することがで きれば臨界電流は向上すると考えられる．市販の超電導テー プ線材は, 高い臨界電流が望まれると思われるが, そのため に製造プロセスが煩雑になりコストが上がるようでは，一概 に高い臨界電流を求めることが最善であるとは言えない.市 販の超電導テープ線材は, 各メーカともコストパフォーマン スが最高になるように努力をしている，また，超電導テープ 線材をどの超電導機器に使用するかによっても, 超電導テー

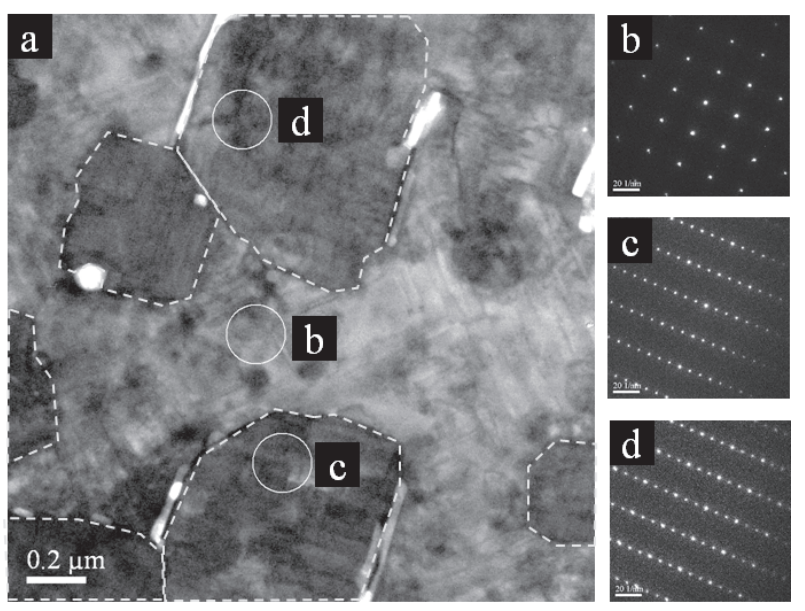

Fig. 6 Cross-sectional TEM of Sumitomo and selected-area electron diffraction patterns from circles described in Fig. 6(a). The grains surrounded by a dash line are a-axis oriented grains. 

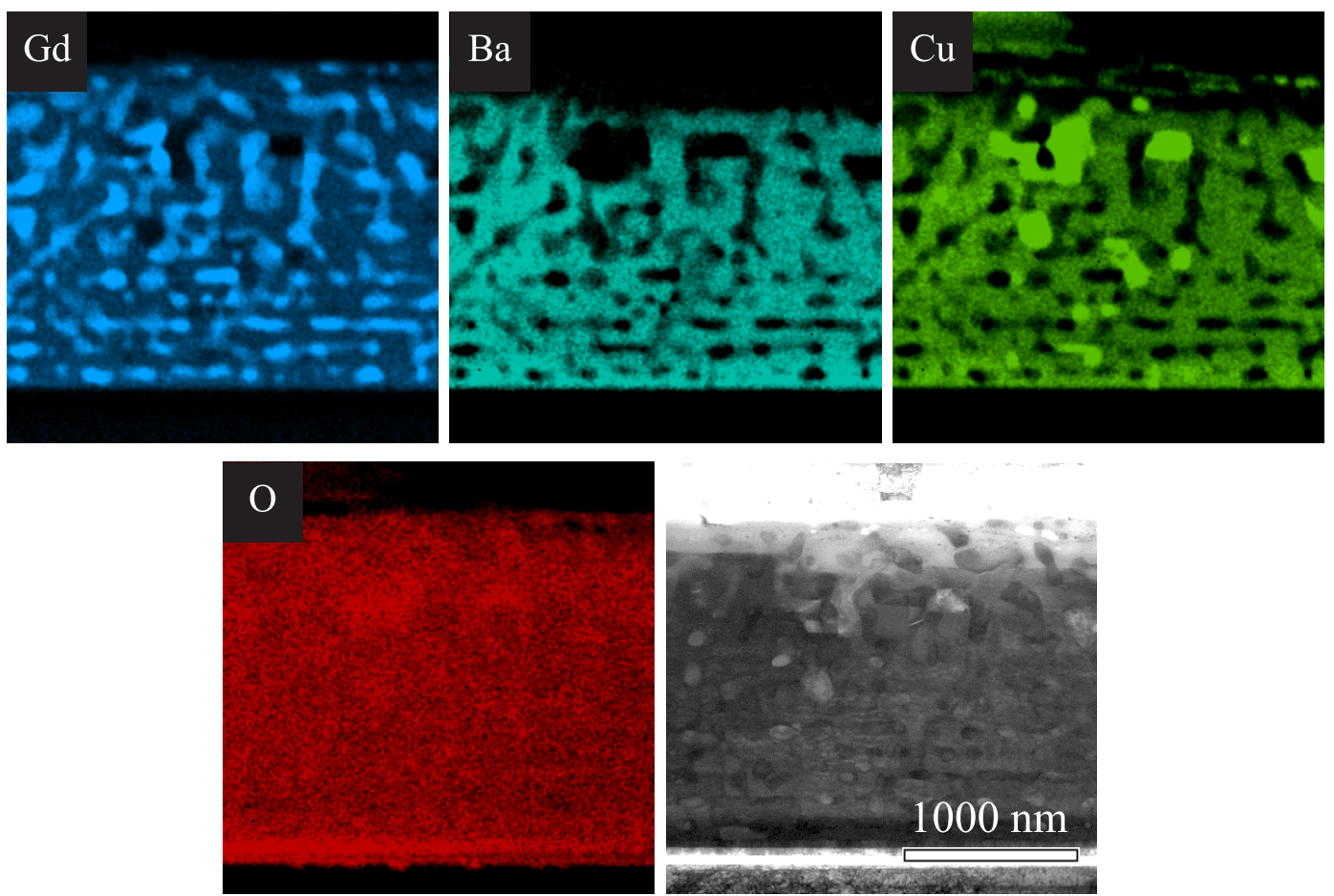

Fig. 7 Cross-sectional STEM image and EDX mappings $\mathrm{Gd}, \mathrm{Ba}, \mathrm{Cu}$ and $\mathrm{O}$ of SuNAM.

プ線材内部の微細組織の不均一性が大きな問題になる場合も あるし，ならない場合もある。したがって，4.2 K 打よび 77 $\mathrm{K}$ の臨界電流測定, 微細組織観察の結果をデータベース化す ることで, 超電導機器開発のためにどの超電導テープ線材を 使用すべきか判断できると考える，今後は，機械特性の結果 を含めてデータベースを充実したいと考えている。

\section{5. ま と め}

市販の 8 本の超電導テープ線材の微細組織観察を行い, $4.2 \mathrm{~K}$ ，磁場中 $(B / / C)$ の臨界電流との関係を示した。超電導 層の作製プロセスに違いにより断面微細組織は線状のコント ラストが主となる線材と粒状のコントラストが主になる線材 の大きく 2 つ分類されることが分かった．粒状のコントラ ストが主になる線材は， $4.2 \mathrm{~K}$ で有効なピンニングサイトが ないため, 磁場中の $I_{\mathrm{C}}$ の低下が大きく, 全ての線材の $I_{\mathrm{C}}$ の 磁場依存性は同じであった。一方，線状のコントラストが主 になる線材は， $4.2 \mathrm{~K}$ で効くピンニングサイトがあり，その ピン力の違いより $I_{\mathrm{C}}$ の低下の度合いが異なることが予想さ れる.さらに, 線状のコントラストが主になる線材は, $\mathrm{BaZrO}_{3}$ ナノロッドの人工ピンを含む線材と含まない線材が あり， $4.2 \mathrm{~K}$ の温度では人工ピンは必ずしも強いピンニング サイトとして効かないが，ナノロッド径を細く，方向を制御 することにより強力なピンニングセンターとして機能するこ とがわかった，さらに，77 K の高 $I_{\mathrm{C}}$ 化について，自己磁場 下の $4 \mathrm{~mm}$ 幅の $I_{\mathrm{C}}$ が $200 \mathrm{~A}$ を越える 3 本の線材について微 細組織の観点から検討した結果， 3 本のうち 2 本は組織制御 を十分に行えば $I_{\mathrm{C}}$ 向上が図れる線材であり，残りの 1 本は 超電導層を厚くするだけで $I_{\mathrm{C}}$ 向上が図れる線材であること がわかった
線材を提供していただいた線材製造業者に感謝致します. また，本研究の一部は JSPS 科研費 JP 15 H03667 の助成を受 けたものです。

文献

1) J.G. Bednorz and K.A. Müller: Z. Physik B 64 (1986) 189-193.

2) "DEMO 5, SUPERCONDUCTING CABLES FOR VERY HIGH POWER TRANSMISSION". The BEST PATHS project. http://www.bestpaths-project.eu/en/demonstration/demo-5, (accessed 2019-05-07)

3) "Cost effective FCL using advanced superconducting tapes for future HVDC grids". The FastGrid project. https://www.fastgrid-h2020.eu/, (accessed 2019-05-07).

4) "Energy Cost Optimization using Superconducting Wind Generators" The EcoSwing project.

https://ecoswing.eu/, (accessed 2019-05-07).

5) "Turboelectric Distributed Propulsion Engine Cycle Analysis for $\mathrm{Hy}$ brid-Wing-Body Aircraft". NASA Glenn Research Center.

https://ntrs.nasa.gov/search.jsp?R=20130010780 2019-0118T04:17: 00+00: 00Z, (accessed 2019-05-07).

6) "Chicago superconductor project will link substations with high-capacity wires". The Energy News Network.

https://energynews.us/2018/11/26/midwest/chicagosuperconductor-project-will-link-substations-with-high-capacitywires/, (accessed 2019-05-07).

7) A. Goyal, F.A. List, J. Mathis, M. Paranthaman, E.D. Specht, D.P. Norton, C. Park, D.F. Lee, D.M. Kroeger, D.K. Christen, J.D. Budai and P.M. Martin: J. Supercond. II (1989) 481-487.

8) Y. Iijima, N. Tanabe, O. Kohno and Y. Ikeno: Appl. Phys. Lett. 60 (1992) 769-771.

9) C.P. Wang, K.B. Do, M.R. Beasley, T.H. Geballe and R.H. Hammond Appl. Phys. Lett. 71 (1997) 2955-2957.

10) K. Tsuchiya, A. Kikuchi, A. Terashima, K. Norimoto, M. Uchida, M. Tawada, M. Masuzawa, N. Ohuchi, X. Wang, T. Takao and S. Fujita: Cryogenics 85 (2017) 1-7.

11) K. Tsuchiya, A. Kikuchi, A. Terashima, K. Suzuki, K. Norimoto, M Tawada, M. Masuzawa, N. Ohuchi, X. Wang, Y. Iijima, T. Takao, S Fujita, M. Daibo and Y. Iijima: IEEE Trans. Appl. Supercond. 27 (2017) 6600205.

12) “2G-HTS Wire”. PRODUCTS, FUJIKURA

http://www.fujikura.co.jp/products/index.html\#/nl-lv2-05/nl-1v205-lv3-01/n1-lv2-05-lv3-01-lv4-01, (accessed 2019-05-07) 
13) “2G-HTS Wires”. PRODUCT, SHANGHAI SUPERCONDUCTOR. http://www.shsctec.com/Pages/SpecialProductList.aspx?ID=42 \&cl=en, (accessed 2019-05-07).

14) “Superconducting Wire”. PRODUCT, SUNAM.

http://i-sunam.com/home/en_product,1,3,1,1,1, (accessed 2019-0507).

15) “2G HTS WIRE”, SUPERCONDUCTOR TO THE FUTURE, SuperOX.

http://www.superox.ru/en/products/974-vtspprovod/, (accessed 2019-05-07).

16) “2G HTS WIRE”, SuperPower.

http://www.superpower-inc.com/content/2g-hts-wire, (accessed 2019-05-07).

17) S. Awaji, T. Suzuki, K. Watanabe, M. Yoshizumi, A. Ibi, T. Izumi, and
Y. Shiohara: Collected Abstracts of the 72nd JSAP Fall Meeting (2011) 11-098.

18) A. Ichinose, K. Tsuchiya, A. Kikuchi and H. Oguro: Collected Abstract of the 2019 Spring Meeting of the Japan Society of Applied Physics (2019) 09-063.

19) Y. Iijima, Y. Adachi, S. Fujita, M. Igarashi, K. Kakimoto, M. Ohsugi, N. Nakamura, S. Hanyu, R. Kikutake, M. Daibo, M. Nagata, F. Tateno and M. Itoh: IEEE Trans. Appl. Supercond. 25 (2015) 6604104.

20) R.H. Hammond and R. Bormann: Phys. C 162-164 (1989) 703-704.

21) Y. Yoshida, Y. Ichino, M. Miura, Y. Takai, K. Matsumoto, A. Ichinose, S. Horii and M. Mukaida: IEEE Trans. Appl. Supercond. 15 (2005) 2727-2730.

22) K. Nakaoka, R. Yoshida, K. Kimura, T. Kato, Y. Usui, T. Izumi and Y. Shiohara: Supercond. Sci. Technol. 30 (2017) 055008. 